\section{Comparison of Minimal Excision and Primary Wound Closure with Limberg Flap Procedure in Adolescent Sacrococcygeal Pilonidal Sinus Surgery}

\author{
Adolesan Sakrokoksigeal Pilonidal Sinus Cerrahisinde \\ Minimal Eksizyon ve Primer Kapama ile Limberg Flap \\ Yönteminin Karşılaştırılması
}

\author{
Cem Karaali $\odot$ \\ Ali Sayan $\odot$ \\ Ismail Sert $\odot$ \\ Mehmet Ustun $\odot$ \\ Cengiz Aydin $\odot$ \\ Mustafa Emiroglu $\odot$
}

\begin{abstract}
Objective: Recently, minimally invasive methods have been used in surgical treatment of adult sacrococcygeal pilonidal sinus (SPS) instead of classical wide excisions. However, there are fewer data about minimally invasive methods in the adolescent age group. Therefore, we aimed to compare our adolescent patients undergoing minimal excision and primary closure (MEPC) with those undergoing Limberg flap (LF) method.

Method: In this study, the data of 80 patients who were operated for sacrococcygeal pilonidal sinus between July 2014 and December 2017 were retrospectively reviewed. Patients who underwent minimal excision with primary closure (MEPC) or Limberg flap (LF) were included in the study. Patients were evaluated in terms of age, sex, body mass index (BMI), length of hospital stay, time to return to work/school, time to complete healing, complication, recurrence and patient satisfaction levels.

Results: No significant difference was found between patient characteristics, complication, recurrence and patient satisfaction rates of these two groups. However, in terms of hospitalization and return to work/ school, MEPC group was found to be statistically advantageous compared with LF group.

Conclusion: MEPC procedure has similar success rates in terms of recurrence, complications and patient satisfaction compared with LF. However, the MEPC procedure has advantages such as allowing faster return to work/school and not requiring hospitalization. Therefore, in adolescents with non-complex and uncommon SPS disease, MEPC procedure may be offered as an alternative treatment option to LF.
\end{abstract}

Keywords: Adolescent, Limberg flap, minimally invasive surgery, patient satisfaction, sacrococcygeal pilonidal sinus

öz

Amaç: Son zamanlarda yetişkin sakrokoksigeal pilonidal sinusün (SPS) cerrahi tedavisinde klasik geniş eksizyonlar yerine minimal invaziv metotlar kullanılmaya başlanmıştır. Ancak adolesan yaş grubunda bu yöntemlerle ilgili daha az veri vardır. Bu nedenle minimal eksizyon ve primer kapama (MEPC) uygulanan adelosan hastalarımızı Limberg flep (LF) yöntemi uygulananklarla karşılaştırmayı amaçladık.

Yöntem: Bu çalışmada 2014 temmuz-2017 aralık tarihleri arasında pilonidal sinüs nedeni ile opere edilen 80 hastanın verileri retrospektif olarak incelendi. Çalışmaya MEPC ile LF uygulanan hastalar dahil edildi. Hastalar yaş, cinsiyet,vücut kitle indeksi, hastanede yatış süresi, işe/okula başlangıç süresi, iyleşme zamanı,komplikasyon, rekkurens ve hasta memnuniyet düzeyleri açısından değerlendirildi.

Bulgular: Her iki grubun hasta karakteristikleri, komplikasyon ve rekurrens oranları ile hasta memnuniyet düzeyleri arasında anlamlı bir fark bulunmadı. Ancak hastanede yatış ve işe/okula dönüşsüresi açısından MEPC grubu LF grubuna göre istatistiksel olarak avantajlı bulunmuştur.

Sonuç: MEPC yöntemi LF ile karşılaştıııldığında rekurrens, komplikasyon ve hasta memnuniyeti açısından benzer başarıya sahiptir. Bununla beraber MEPC yönteminin daha hızlı işe/okula dönüşe izin vermesi ve hastaneye yatıs gerektirmemesi gibi avantajları vardır. Bu nedenle kompleks ve yaygın olmayan SPS hastalığına sahip adolesanlarda MEPC yöntemi, LF'e alternatif bir tedavi seçeneği olarak hastalara sunulabilir.

Anahtar kelimeler: Adolesan, Limberg flep, minimal invaziv cerrahi, hasta memnuniyeti, sakrokoksigeal pilonidal sinüs
Alındığı tarih: 08.02.2020

Kabul tarihi: 26.02 .2020

Online Yayın tarihi: 30.03.2020

Cem Karaali

Tepecik Education and

Research Hospital,

General Surgery

Izmir - Turkey

cemkaraali@gmail.com ORCiD: 0000-0003-2743-7360

I. Sert 0000-0001-5190-9124

M. Ustun 0000-0003-2646-5239

C. Aydin 0000-0003-4713-2871

M. Emiroglu 0000-0002-4968-2570

Tepecik Education and

Research Hospital, General Surgery,

Izmir, Turkey

A. Sayan 0000-0002-1866-8899 Tepecik Education and Research Hospital, Pediatric Surgery, Izmir, Turkey 


\section{INTRODUCTION}

Sacrococcygeal pilonidal sinus (SPS) is a disease that usually affects young males. The incidence in adolescence is reported to be $1.2-2 / 10.000{ }^{(1)}$. Although SPS is usually symptomatic, asymptomatic cases can also be detected. While it has not been possible to indicate any advantage of treating asymptomatic SPS disease ${ }^{(2)}$, symptomatic patients should be treated since the disease affects the person's quality of life. Many procedures have been described for the treatment of symptomatic SPS. However, treatment of adolescent SPS patients is generally steered in line with the treatment of adult patients. However, similar treatments to adolescent and adult age groups may not show similar recurrence rates ${ }^{(3)}$. In this context, when determining the treatment to be selected in adolescent SPS patients, care should be taken to ensure that the procedure has a low recurrence and complication rate, has a low impact on the quality of life of the patient and is easy to implement ${ }^{(4)}$. In the literature, procedures commonly used in the treatment of SPS are either to leave the wound to secondary healing after extensive excision of SPS or to close the wound with flap or without flap ${ }^{(5)}$. However, each of these procedures has its own advantages and disadvantages ${ }^{(6)}$. For example, wounds left for secondary healing recover much later than primary closure wounds, but relapse rates are lower. However, when the wounds closed primarily in the midline or not are compared, the recurrence, wound infection rates and recovery times of the wounds closed in the midline are higher (7). Therefore, in recent years as an alternative to the procedures described above, surgical and nonsurgical minimally invasive procedures which are easy to apply, allow rapid return to work/school, and have reportedly acceptable recurrence and complication rates ${ }^{(6,8)}$. Minimally invasive surgical procedures usually performed through a limited incision or excision of the sinuses and orifices. The resulting wound can be left open, curetted or partially treated (9-13). Similar to these procedures, we performed a minimal incision in the sinuses and orifices and included only the diseased tissue in the excision. However, unlike the studies mentioned above, we completely closed the wound. In the procedure described, the diseased tissue is eliminated with minimal loss of intact tissue. In flap procedures that are frequently used in the treatment of SPS, although low recurrence rates are presented, increased tissue loss and wound-related problems have been defined ${ }^{(14)}$

Therefore, we aimed to compare the MEPC procedure with the Limberg flap (LF) procedure, which is frequently used in the treatment of SPS in adolescent patients. According to our hypothesis, minimal excision and primary closure (MEPC) in adolescents with SPS will cause less wound problems than LF with acceptable recurrence rates.

\section{MATERIAL and METHODS}

Local ethics committee approval was received for this study (SBU TEAH 14/48). Adolescents aged 14-19 years who underwent MEPC or LF for sacrococcygeal pilonidal sinus between July 2014 and December 2017 were included in the study. All patients signed a voluntary consent form before the procedure. Patient files were reviewed retrospectively. The patients in the MEPC group were treated with local anesthesia in the outpatient clinics and none of them were hospitalized. The LF group was operated under spinal anesthesia in the operating room. Postoperatively, all patients were prescribed a painkiller to be used in case of need. The patients were called for visits weekly for the first month and monthly afterwards. The treatment of the patients whose wounds did not close at the end of the third month or whose wounds reopened after this period was deemed to be a failure

Satisfaction levels of the patients were measured with a Likert-type satisfaction questionnaire. The questions asked postoperatively in the questionnaire were related to procedure tolerance, postoperative pain, complication, return to daily work and cosmetic results (0-2; poor, 3-4; fair, 5-6; average, 7-8; good; 9-10 excellent).

The cases were evaluated in terms of age, sex, body mass index, morbidity, surgical technique, recurrence, complications, recovery time, return to work/school time and total satisfaction scores.

Exclusion criteria; Patients with abscess or cellulitis at the time of diagnosis and SPS patients with 
C. Karaali et al. Comparison of Minimal Excision and Primary Wound Closure with Limberg Flap Procedure in Adolescent Sacrococcygeal Pilonidal Sinus Surgery

recurrent disease were excluded from the study. In addition, patients with complex SPS disease were not included in the MEPC group.

\section{Outcome parameters}

\section{Primary outcome parameter}

The primary outcome parameter of our study was to compare the recurrence and complication rates of both procedures.

\section{Secondary outcome parameters}

Our secondary outcome parameter of our study was to compare the recovery time, return to work/ school time and satisfaction rates of both groups.

\section{Surgical Procedures}

In the MEPC procedure used in our study, we make a minimal skin incision involving the sinuses and orifices. However, if necessary, we can incorporate a small area of skin that includes only sinuses

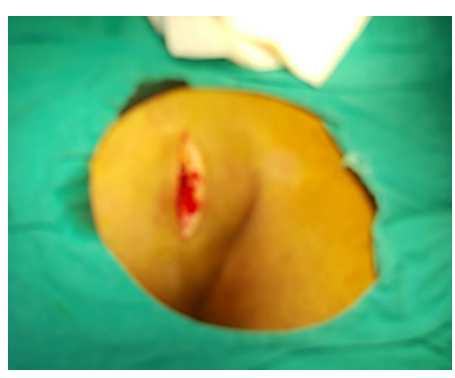

a

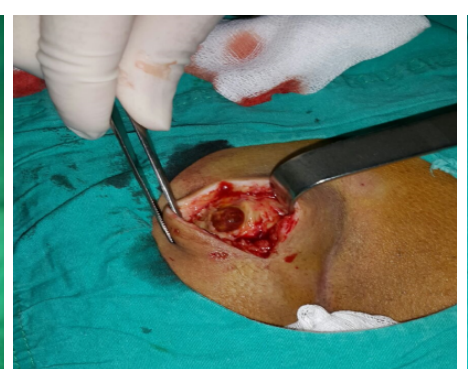

b

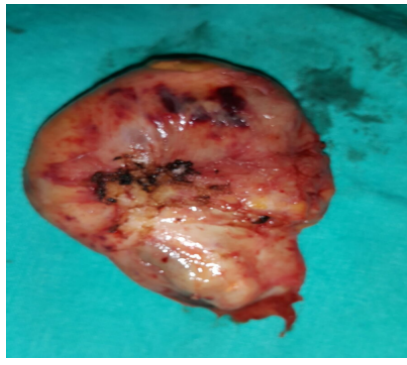

C

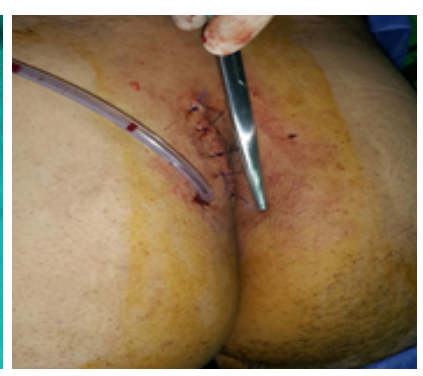

d

Figure 1. a) Incision on the lesion. b) preparation of skin flaps. c) specimen. d) wound sutured.

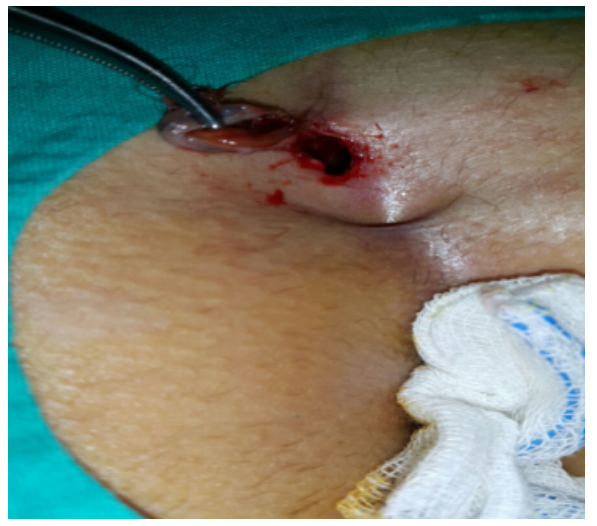

a

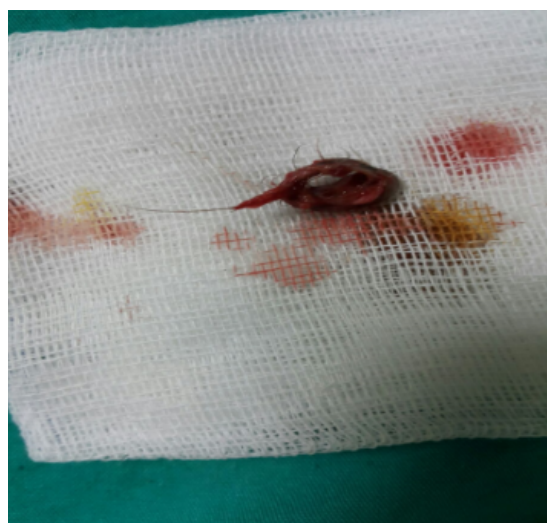

b

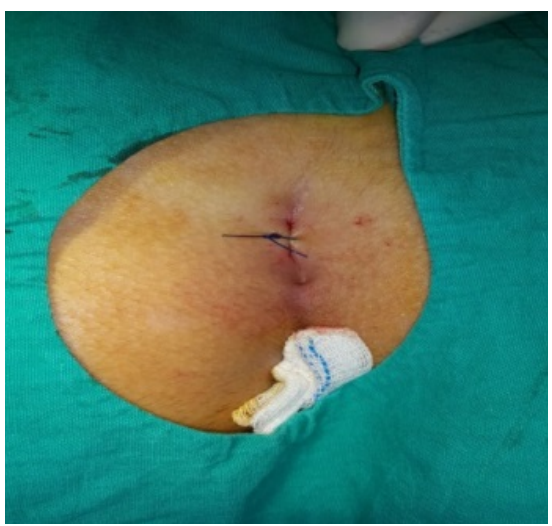

C

Figure 2. a) A small incision in the PS was entered into the cavity and the diseased area was removed. b) there is almost no solid tissue around the removed specimen. c) incision was closed with a single suture.

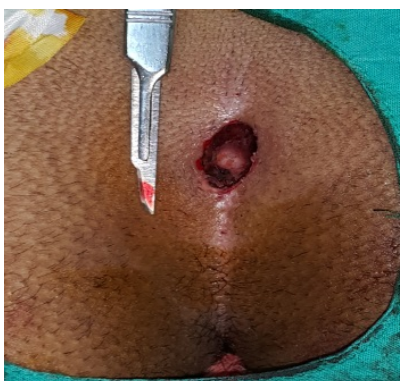

a

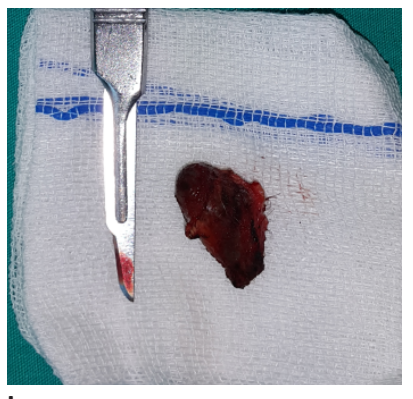

b

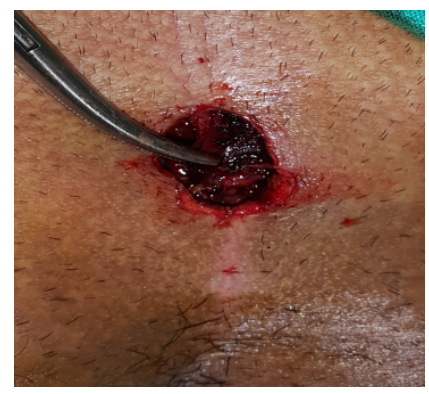

c

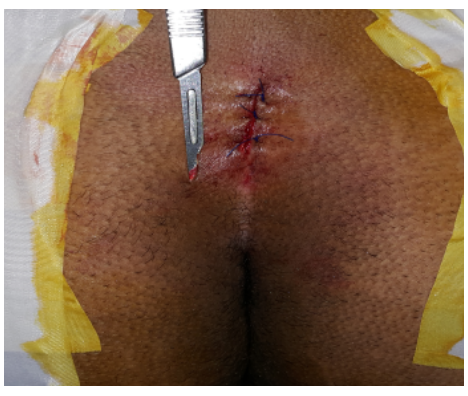

d

Figure 3. a) The diseased area was removed with a small incision. b) specimen. c) unilateral flap. d) wound sutured. 
and orifices. We then remove only the circumference of the cavity and the sinus tract by taking as little intact tissue as possible (with the help of scalpel or cautery). If the cavity does not reach the presacral area, we do not deepen the excision towards the presacral area. We also do not use methylene blue during this process. If the resulting gap is too large to be closed by skin suture, we bring the wound closer by performing single or double release incisions on the fascia. We determine the use of drains according to the needs. Skin sutures are tied individually with $2 / 0$ prolene and dressing is performed with dry gauze. Preoperatively, antibiotic prophylaxis (SP) was not used in the MEPC group. Surgical technique of MEPC is presented in Figure 1-3.

In the LF procedure, we have traditionally performed a rhomboid incision involving all sinuses and orifices. The diseased area was excised to the presacral fascia with intact tissue. The resulting cavity was closed with the classic Limberg flap procedure ${ }^{(15,16)}$. Preoperative single dose SP was used in Limberg flap procedure.

\section{Statistics}

Statistical analysis was performed using SPSS V.17.0 software. The suitability of the variables to normal distribution was analyzed using analytical methods (Kolmogorov-Smirnov/Shapiro-Wilk tests). Descriptive statistics were performed using mean \pm standard deviation for normally distributed variables. In the comparison of independent groups with continuous variables matching normal distribution, t-test was used, and Mann-Whitney $U$ test was used for variables that did not conform to normal distribution. Pearson's chi-square test or Fisher's exact chisquare test were used to compare the groups with discrete variables. A p-value below 0.05 was considered statistically significant.

\section{RESULTS}

Eighty patients were included in the study. Mean age of the patients (16.9 \pm 1.2 [min-max 14-19] years) , male to female ratio (3/2), mean body mass index (BMI) (24.9 \pm 4.1 [min-max 16-37.1)], follow-up time (24.2 \pm 12.6 (min-max). 7-51), the complication rate $(21.25 \%)$ and the recurrence rate (16.25\%) were determined as indicated.

There were 34 patients in the MEPC group. The mean age was $16.9 \pm 1.4$ (min-max 14-19) years. Recurrence occurred in 8 patients $(23.5 \%)$ and complications developed in 8 patients (23.5\%). Recovery time was $23.1 \pm 12.0$ days, time to return to work/ school was $8.8 \pm 5.3$ days, and mean satisfaction score

Table 1. Characteristics of the patients according to surgery groups. Bold values indicate statistical significance.

\begin{tabular}{|c|c|c|c|}
\hline \multirow[b]{2}{*}{ Characteristics } & \multicolumn{3}{|c|}{ Surgery group } \\
\hline & MEPK $(n=34)$ & $\operatorname{LF}(n=46)$ & p-value \\
\hline Female & $7(79.4 \%)$ & $33(71.7 \%)$ & 0.433 \\
\hline Male & $27(20.6 \%)$ & $13(28.3 \%)$ & \\
\hline Age (years) & $16.9 \pm 1.4(14-19)$ & $17.1 \pm 1.1(15-19)$ & 0.450 \\
\hline Time until return to work/school (days) & $8.8 \pm 5.4(1-22)$ & $16.2 \pm 3.9(8-24)$ & 0.0001 \\
\hline Time until complete healing (days) & $23.1 \pm 12.1(10-68)$ & $25.5 \pm 6.4(17-47)$ & 0.257 \\
\hline Total complication n (\%) & $8(23.5 \%)$ & $9(19.6 \%)$ & 0.269 \\
\hline Total wound dehiscence & $0(0 \%)$ & $1(2.1 \%)$ & 1.000 \\
\hline Partial wound dehiscence & $4(11.7 \%)$ & $3(6.5 \%)$ & 0.450 \\
\hline Ecchymosis & $2(5.9 \%)$ & $0(0 \%)$ & 0.180 \\
\hline Patient satisfaction (in the $1^{\text {st }}$ year) & $8.4 \pm 1.7(4-10)$ & $7.8 \pm 1.5(4-10)$ & 0.122 \\
\hline
\end{tabular}

Data are presented as mean \pm standard deviation, median (minimum-maximum) or number (\%), where appropriate. 
C. Karaali et al. Comparison of Minimal Excision and Primary Wound Closure with Limberg Flap Procedure in Adolescent Sacrococcygeal Pilonidal Sinus Surgery

Table 2. Summarizes the results of the surgical groups in our study and similar surgical groups in the literature.

\begin{tabular}{|c|c|c|c|c|c|c|c|}
\hline Literature & $\mathbf{n}$ & $\begin{array}{l}\text { Recurrens } \\
\text { (\%) }\end{array}$ & $\begin{array}{c}\text { Complication } \\
\text { (\%) }\end{array}$ & $\begin{array}{l}\text { Healing } \\
\text { time }\end{array}$ & $\begin{array}{c}\text { Work/school/daily } \\
\text { activity (day) }\end{array}$ & $\begin{array}{l}\text { Satisfaction } \\
\text { rate }\end{array}$ & $\begin{array}{l}\text { Follow-up time } \\
\text { (months) }\end{array}$ \\
\hline${ }^{*}$ Chen Speter et. al. & 21 & 28 & 10 & 10-122 days & 10 & NR & $28(17-37)$ \\
\hline *Pankaj Garg et. al. & 1445 & 4.40 & 1.40 & 21-72 days & $8.4(3-14)$ & NR & \\
\hline *Angelo Di Castro et. al. & 2347 & 5.8 & 4.3 & 30 (1-21 week) & 2 & NR & $16(1-55)$ \\
\hline *Kaveh Khodakaram et. al. & 113 & 32 & NR & NR & $1(3.5)$ & NR & 39.6 \\
\hline${ }^{*}$ Christopher Soll et. at. & 257 & 7 & 5 & 5 weeks & $7(1-90)$ & NR & \\
\hline${ }^{*} \mathrm{MEPC}$ & 34 & 23.5 & 23.5 & $23.1 \pm 12.0$ & $8.8 \pm 5.3$ & $8.3 \pm 1.6$ & $21.2 \pm 12.3$ \\
\hline \#Haluk R. Unalp et. al. & 111 & 1.5 & 28.7 & NR & $15.2( \pm 4.9)$ days & & $45.4 \pm 18.5$ \\
\hline \#Zulfiqar Ahmed et. al. & 75 & NR & NR & NR & $15.3 \pm 1.2$ & NR & NR \\
\hline \#K. Arslan et. al. & 96 & 6.3 & 20.8 & $29.0 \pm 9.9$ & $20.8 \pm 6.5$ & $74 \%$ & $7.3 \pm 3.4$ \\
\hline "Feza Karakayali et. al. & 70 & 1.4 & 12.9 & $23.7 \pm 11.2$ & $17.9 \pm 9.3(2-46)$ & $7.7 \pm 1.6$ & 15 \\
\hline \#Our LF group & 46 & 10.9 & 19.6 & $25.5 \pm 6.4$ & $16.2 \pm 3.8$ & $7.8 \pm 1.5$ & $24.1 \pm 12.8$ \\
\hline
\end{tabular}

*Treated with minimally invasive surgery

"Treated with Limberg Flap

NR: No results

was $8.3 \pm 1.6$

There were 46 patients in the LF group. The mean age of the LF group was $17.1 \pm 1.1$ (min-max $15-19)$. Recurrence occurred in 5 patients (10.9\%) and complications developed in 9 patients (19.6\%). In the LF group, recovery time was $25.5 \pm 6.4$ days, time to return to work/school was $16.2 \pm 3.8$ days, hospitalization time was $1.1 \pm 0.4$ days, and mean satisfaction score was $7.8 \pm 1.5$. Complete wound separation was found in one of 9 patients who developed complications. In addition, partial opening of inferior flap was detected in 3 , maceration in 3 , and complications of wound infection in 2 patients.

While there was no significant difference between patient characteristics, complication, recurrence and patient satisfaction rates of both groups, the duration of hospitalization and time to return to work/school were statistically different. Demographic characteristics and postoperative data of the groups in our study are shown in Table 1 . Table 2 summarizes the results of the surgical groups in our study and similar surgical groups in the literature.

\section{DISCUSSION}

This study gives an idea about the usability of MEPC, a minimally invasive procedure in adolescents with SPS. This finding is important, since the MEPC method used in our study resulted in recurrence, complications and patient satisfaction rates similar to LF procedure. These results underline that similar success rates can be achieved with minimally invasive surgery in adolescents with non-complex SPS without using flap procedure.

In our study, it was found that LF procedure was more successful in terms of recurrence than MEPC procedure, but this difference did not reach to a statistical significance $(p>0.05)$. John Bascom ${ }^{(17)}$ has stated that moisture and anaerobic conditions in the natal cleft led to maceration in the epidermis, loss of function in the natural barrier and impaired wound healing. With the Limberg flap procedure, the anal cleft is removed and the midline is shifted sideways. In this way, the predisposing factors mentioned above are eliminated and a low recurrence rate is obtained. Recurrence rates of LF in the literature support this theory and range between low rates $(1.5-13 \%)^{(14,18,19)}$. In our study, the recurrence rate of LF was $10.9 \%$, which is consistent with the literature. In the MEPC procedure that we applied in our study, only the diseased area is removed and the wound is usually closed in the midline.

Therefore, predisposing factors cannot be eliminated sufficiently according to John Bascom's theory. In addition, closure of the wound in the midline is not recommended because midline suture is associate with high recurrence rates ${ }^{(4,7)}$. Although predisposing factors could not be eliminated sufficiently in the MEPC group in our study and the wound was closed in the midline, the fact that the recurrence 
rates found to be similar to LF seems to contradict these theories. However, in the literature, lower recurrence and complication rates have been found similar to flap procedures in the two studies where the wound was primarily closed with tension-free sutures in the middle line after extended excision of SPS ${ }^{(18,20)}$. This shows that tension-free closure, which is known and preferred for every wound closure, is also valid and important in the treatment of SPS. The fact that the MEPC procedure provides a similar recurrence rate to the LF procedure may suggest that removal of the diseased area and tension-free closures are an adequate treatment option. But, when the other minimally invasive surgical procedures in the literature are examined, it is seen that the recurrence rates vary between $4.4-32 \%{ }^{(9-13)}$. In most of these methods, a limited excision/incision is made to the sinus or orifices and the wound is left open. Among these, only Khodakaram et al. ${ }^{(10)}$ closed the wound after excision as in our study. However, unlike our study, the lateral tract was left open for maintenance of the drainage. However, in the aforementioned study, the average recurrence rate was determined to be $32 \%$ during a 5 -year follow-up. This rate is higher than the recurrence rates in our study. However, since there is a direct correlation between follow-up and recurrence ${ }^{(21)}$, it should be kept in mind that our recurrence rates may increase with the prolongation of the follow-up period. As a result, in order to say that the MEPC procedure used in our study has similar recurrence rates to the LF procedure, prospective studies with higher number of patients, and longer follow-up periods are needed. In addition, considering that LF procedure is also applied to patients with complex diseases, it should not be forgotten that there is a bias in favor of MEPC procedure.

When the patients in our study were examined in terms of complications, there was no significant difference between the two groups. In the literature, the complication rates of the LF method range between $5.7-49 \%{ }^{(14,19,22)}$ and are consistent with the complication rates in our study. High complication rates in LF are one of the disadvantages of the method and most of the complications are caused by wound separation and maceration as in our study $(14,22)$. However, in minimally invasive surgical proce- dures described in the literature, complication rates vary as low as $1.4-10 \%{ }^{(9-13)}$. However, in our study, the complication rate of MEPC method was found to be higher as opposed to minimally invasive surgical procedures. In none of the aforementioned lowcomplication minimally invasive surgical procedures, the wound has been completely closed after sinus excision/incision. In addition, in the Gips procedure (9) and in the study of Khodakaram et al. ${ }^{(10)}$, the sinuses were removed separately, leaving intact areas of the skin in between. We combined the sinuses and orifices to be removed and then performed cavity excision afterwards as well. This way, we both cut the unaffected intact skin in between, and had to shift a flap to close the gaps when needed. In addition, although minimally invasive procedures are generally recommended to be used in patients with small lesions ${ }^{(5,23)}$, we applied the MEPC method to large lesions, too. However, as a result of these operations that were performed under local anesthesia and usually with a small incision, wound tension might not have been reduced sufficiently in some cases. Most probably, because of these reasons our complication rates might have been found higher with respect to the other minimally invasive surgical procedures in the literature. Again for the same reasons, although there is less tissue loss compared with the LF procedure, the MEPC method may not have shown a superiority in terms of complications in comparison with LF. In addition, in LF procedure, the desired amount of tissue can be shifted to the wound formed after SPS excision and the wound can be filled without tension. Therefore, as stated in other minimally invasive surgical procedures in the literature, the application of MEPC method in small and uncomplicated SPS patients would be a more appropriate approach ${ }^{(5,23)}$.

When the treatment modalities for SPS are discussed in the literature, it is seen that the main issue is recurrence and complications. However, recurrence and complication are not the only determinants of SPS treatment. In particular, the factors affecting the quality of life such as school attendance, sportive activities and socialization in the adolescent age group should not be ignored when appropriate treatment is selected ${ }^{(6)}$. In our study, no significant difference was observed between MEPC and LF met- 
hods in the recovery time and patient satisfaction rates. However, the MEPC provided earlier return to work/school than the LF. In addition, the MEPC method has advantages such as not requiring hospitalization and preoperative antibiotic prophylaxis. In our study, the mean recovery time, time to return to work/school, and patient satisfaction rate of LF are consistent with the literature ${ }^{(15,16,19,24)}$. Similarly, the recovery time and time to return to work/school time following minimally invasive surgical procedures in the literature have been found to be similar to the MEPC method in our study ${ }^{(9-12)}$. However, the satisfaction rates of these minimally invasive surgical procedures have not been measured. Although the MEPC method in our study was found to be higher than the LF procedure in terms of patient satisfaction rates, the fact that there was no significant difference between them is an important consideartion. This is because patient satisfaction rates are generally associated with recurrence rates ${ }^{(25)}$. The fact that no significant difference was found between the MEPC group and LF group in our study supports this finding. However, recurrence alone does not determine the patient satisfaction. Patient satisfaction consists of a combination of procedure tolerance, postoperative pain, complication, time to return to daily work and cosmetic findings. Although the MEPC method does not require hospitalization, and allows for a quick return to work/school and has a smaller wound at the end of the surgery, it is interesting to note that both groups have similar patient satisfaction rates. This finding is in contradiction with the Youssef et al.'s thesis ${ }^{(26)}$ that not only recurrence and complications but also other factors affecting quality of life should be taken into consideration in determining patient satisfaction rates. Since in our study we had information about the treatment processes, and outcomes only in the patient group, we could not obtain the opportunity to compare the treatment processes with the patients of the other group. Probably for this reason, satisfaction levels of our patients are mainly affected by recurrences and complications.

Limitations; In the MEPC group, the procedure was aimed to be performed in a restricted area and the intervention was performed under local anest- hesia. Accordingly, MEPC method was not applied to the patients with complex SPS disease. However, this has led to the formation of the MEPC group from SPSs with limited disease and homogeneity within the group itself.

In coclusion, the MEPC method showed similar results in terms of recurrence and complications when compared with the LF method. In addition, the MEPC method has advantages such as allowing quick return to work/school, no need for hospitalization, and high patient satisfaction rates. Therefore, in adolescents with non-complex and uncommon SPS, MEPC may be offered as an alternative treatment to LF.

\section{ACKNOWLEDGMENT}

Authors' contributions: $\mathrm{CK}$ and ME designed the study; CK, IS, and MU performed the study; IS and MU analyzed the data; CK and ME wrote and revised the manuscript. All authors read and approved the final manuscript.

Ethics Committee Approval: The study protocol was approved by the Local Ethics Committee of SBU Izmir Tepecik Education and Research Hospital (2017/14-48). Conflict of Interest: The author(s) declare that they have no potential conflicts of interest with respect to the research, authorship and/or publication of this article.

Funding: This research received no specific grant from any funding agency in the public, commercial, or notfor-profit sectors.

Informed Consent: As the study was retrospective, consent was not obtained from the patients.

\section{REFERENCES}

1. Nasr A, Ein SH. A pediatric surgeon's 35-year experience with pilonidal disease in a Canadian children's hospital. Canadian Journal of Surgery. 2011;54(1):39. https://doi.org/10.1503/cjs.028509

2. Doll D, Friederichs J, Düsel W, Fend F, Petersen S. Surgery for asymptomatic pilonidal sinus disease. International journal of colorectal disease. 2008;23(9):839. https://doi.org/10.1007/s00384-008-0476-2

3. Stauffer $V$, Luedi $M$, Kauf $P$, Schmid $M$, Diekmann $M$, Wieferich $\mathrm{K}$, et al. Common surgical procedures in pilonidal sinus disease: a meta-analysis, merged data analysis, and comprehensive study on recurrence. Scientific reports. 2018;8(1):3058.

https://doi.org/10.1038/s41598-018-20143-4 
4. Al-Khamis A, McCallum I, King PM, Bruce J. Healing by primary versus secondary intention after surgical treatment for pilonidal sinus. The Cochrane database of systematic reviews. 2010(1):CD006213.

https://doi.org/10.1002/14651858.CD006213.pub3

5. Iesalnieks I, Ommer A, Petersen S, Doll D, Herold A. German national guideline on the management of pilonidal disease. Langenbeck's Archives of Surgery. 2016;401(5):599-609. https://doi.org/10.1007/s00423-016-1463-7

6. Hardy EJO, Herrod PJ, Doleman B, Phillips HG, Ranat R, Lund $J N$. Surgical interventions for the treatment of sacrococcygeal pilonidal sinus disease in children: A systematic review and meta-analysis. Journal of Pediatric Surgery. 2019. https://doi.org/10.1016/j.jpedsurg.2019.02.058

7. McCallum I, King PM, Bruce J, Ahmed AK. Healing by primary versus secondary intention after surgical treatment for pilonidal sinus. Cochrane Database of Systematic Reviews. 2007(4).

https://doi.org/10.1002/14651858.CD006213.pub2

8. Emiroğlu M, Karaali C, Esin H, Akpınar G, Aydın C. Treatment of pilonidal disease by phenol application. Turkish Journal of Surgery. 2017;33(1):5. https://doi.org/10.5152/UCD.2016.3532

9. Di Castro A, Guerra F, Levi Sandri GB, Ettorre GM. Minimally invasive surgery for the treatment of pilonidal disease. The Gips procedure on 2347 patients. International Journal of Surgery. 2016;36(Pt A):201-5. https://doi.org/10.1016/j.ijsu.2016.10.040

10. Khodakaram K, Stark J, Hoglund I, Andersson RE. Minimal Excision and Primary Suture is a Cost-Efficient Definitive Treatment for Pilonidal Disease with Low Morbidity: A Population-Based Interventional and a Cross-Sectional Cohort Study. World Journal of Surgery. 2017;41(5):1295302. https://doi.org/10.1007/s00268-016-3828-z

11. Soll C, Dindo D, Steinemann D, Hauffe T, Clavien PA, Hahnloser D. Sinusectomy for primary pilonidal sinus: less is more. Surgery. 2011;150(5):996-1001. https://doi.org/10.1016/j.surg.2011.06.019

12. Speter C, Zmora O, Nadler R, Shinhar D, Bilik R. Minimal incision as a promising technique for resection of pilonidal sinus in children. Journal of Pediatric Surgery. 2017;52(9):1484-7. https://doi.org/10.1016/j.jpedsurg.2017.03.040

13. Garg P, Menon GR, Gupta V. Laying open (deroofing) and curettage of sinus as treatment of pilonidal disease: a systematic review and meta-analysis. ANZ Journal of Surgery. 2016;86(1-2):27-33. https://doi.org/10.1111/ans.13377

14. Käser S, Zengaffinen R, Uhlmann M, Glaser C, Maurer C. Primary wound closure with a Limberg flap vs. secondary wound healing after excision of a pilonidal sinus: a multicentre randomised controlled study. International Journal of Colorectal Disease. 2015;30(1):97-103. https://doi.org/10.1007/s00384-014-2057-x

15. Arslan K, Kokcam SS, Koksal H, Turan E, Atay A, Dogru O.
Which flap method should be preferred for the treatment of pilonidal sinus? A prospective randomized study. Techniques in Coloproctology. 2014;18(1):29-37. https://doi.org/10.1007/s10151-013-0982-2

16. Karakayali F, Karagulle E, Karabulut Z, Oksuz E, Moray G, Haberal M. Unroofing and marsupialization vs. rhomboid excision and Limberg flap in pilonidal disease: a prospective, randomized, clinical trial. Diseases of the Colon \& Rectum. 2009;52(3):496-502.

https://doi.org/10.1007/DCR.0b013e31819a3ec0

17. 154:118-122 BJRpoAJS.

18. Sevinc B, Karahan O, Okus A, Ay S, Aksoy N, Simsek G. Randomized prospective comparison of midline and offmidline closure techniques in pilonidal sinus surgery. Surgery. 2016;159(3):749-54. https://doi.org/10.1016/j.surg.2015.09.024

19. Unalp HR, Derici H, Kamer E, Nazli O, Onal MA. Lower recurrence rate for Limberg vs. V-Y flap for pilonidal sinus. Diseases of the Colon and Rectum. 2007;50(9):1436-44. https://doi.org/10.1007/s10350-007-0276-8

20. Okuş A, Sevinç B, Karahan Ö, Eryılmaz MA. Comparison of Limberg flap and tension-free primary closure during pilonidal sinus surgery. World Journal of Surgery. 2012;36(2):431-5. https://doi.org/10.1007/s00268-011-1333-y

21. Doll D. 5-and 10-year recurrence rate is the new gold standard in pilonidal sinus surgery benchmarking. Medical Principles and Practice. 2010;19(3):216-7. https://doi.org/10.1159/000285292

22. Cihan A, Ucan BH, Comert M, Cesur A, Cakmak GK, Tascilar O. Superiority of asymmetric modified Limberg flap for surgical treatment of pilonidal disease. Diseases of the Colon \& Rectum. 2006;49(2):244-9. https://doi.org/10.1007/s10350-005-0253-z

23. Segre D, Pozzo M, Perinotti R, Roche B. The treatment of pilonidal disease: guidelines of the Italian Society of Colorectal Surgery (SICCR). Techniques in Coloproctology. 2015;19(10):607-13. https://doi.org/10.1007/s10151-015-1369-3

24. Ahmed Z, Shahid M, Malik MS, Hussain S. Comparison of Karydakis technique with Limberg flap procedure for sacrococcygeal pilonidal sinus disease in terms of hospital stay and work loss. Pakistan Armed Forces Medical Journal. 2017;67(1):141-44.

25. Doll D, Luedi MM, Evers T, Kauf P, Matevossian E. Recurrencefree survival, but not surgical therapy per se, determines 583 patients' long-term satisfaction following primary pilonidal sinus surgery. International Journal of Colorectal Disease. 2015;30(5):605-11. https://doi.org/10.1007/s00384-015-2130-0

26. Youssef T, El-Awady S, Farid M. Tension-free primary closure compared with modified Limberg flap for pilonidal sinus disease: a prospective balanced randomized study. The Egyptian Journal of Surgery. 2015;34(2):85. https://doi.org/10.4103/1110-1121.155716 